\title{
Lozan’a Giden Süreçte Mudanya Ateşkes Antlaşması ${ }^{1}$
}

\author{
Ömer Faruk KIRMIT²
}

Başvuru Tarihi: 07.12.2020

Kabul Tarihi: 22.03 .2021

Makale Türü: Araştırma Makalesi

\section{Öz}

Ateşkes; savaşan iki kuvvetin karşılıklı olarak savaşı durdurması demektir. Genellikle Ateşkes ile Mütareke kelimesi birbirlerinin eş anlamlısı olarak kullanılmakla beraber bazen bunların yerine Bırakışma da denilmektedir. Mudanya Ateşkes Antlaşması, Ankara Hükümetinin Batı cephesi karşısında gösterdiği askeri başarılar neticesinde TBMM ile İtilaf devletleri arasında imzalanmış siyasi bir belgedir. Antlaşma, 20. yüzyllın ilk çeyreğinde Lozan'a giden süreçte çok önemli bir yapı taşını oluşturmuştur. Bu önemi gösterir derecede Mudanya Ateşkes Antlaşması ile ilgili birçok çalışma yapılmış ve yapılan bu çalışmalarda antlaşma bütün yönleriyle ele alınmıştır. Dolayısıyla biz bu makalede, Mudanya Ateşkes Antlaşması'nın imzalanmasını sağlayan Büyük Taarruz ile o dönem yaşanan gelişmeleri değerlendirdik ve olayları farklı bir bakış açısıyla yorumladık. 3-11 Ekim 1922'de toplanılan ve toplantı sonucunda imzalanan Mudanya Ateşkes Antlaşması, Lozan'dan önce TBMM’nin imzaladığı büyük antlaşmalardan birisidir. Antlaşma sonuçları itibariyle üç yıldır devam eden Yunan işgalini sona erdirmiş ve Doğu Trakya'nın savaş yapılmadan boşaltılmasını sağlamıştır. Lozan Antlaşmasına gidilen süreçte TBMM'nin elini güçlendirmiş ve masaya herkesle eşit bir şekilde oturmasının yolunu açmıştır.

Anahtar Kelimeler: Büyük Taarruz, Mudanya Ateşkes Antlaşması, Atatürk, İsmet Paşa, Harrington, Yunanistan

Atıf: Kırmıt, Ö. F. (2021). Lozan'a giden süreçte Mudanya Ateşkes Antlaşması. Anadolu Üniversitesi Sosyal Bilimler Dergisi, 21(1), 145-162.

\footnotetext{
${ }^{1}$ Bu çalışma etik kurul izin belgesi gerektirmemektedir.

${ }^{2}$ Hacıbayram Veli Ünversitesi Polatlı Fen Edebiyat Fakültesi Tarih Bölümü, kirmit1989@hotmail.com, ORCID: 0000-0003-1219-2647
} 


\title{
Armistice of Mudanya in the Process Through Lausanne Agreement
}

\author{
Ömer Faruk KIRMIT³
}

\begin{abstract}
Truce means that two fighting forces mutually stop the war. Generally, the words Armistice and Truce are used as synonyms for each other. Sometimes they are also called as "letting go". The Mudanya Armistice Agreement is a political document signed between the Turkish Grand National Assembly and the Entente states as a result of the military success of the Ankara government against the Western front. The treaty constituted a very important building block in the process leading to Lausanne in the first quarter of the 20th century. As a matter of fact, although many studies have been carried out on the Mudanya Armistice Agreement before, it has been observed that there are some incomplete expressions in the process leading to the agreement. The purpose of this article is; rather than revealing new information on the subject, it is to explain the developments in the process leading to the signing of the treaty with the Great Attack
\end{abstract}

Keywords: Great Attack, Armistice of Mudanya, Atatürk, İsmet Pasha, Harrington, Greece

\footnotetext{
${ }^{3}$ Hacıbayram Veli University Polatlı Science and Literature Faculty Department of History, kirmit1989@hotmail.com, ORCID: 0000-0003-12192647
} 


\section{Giriş}

1914-1918 yılları arasında cereyan eden I. Dünya Savaşı’nda Osmanlı Devleti yenilmiş ve 30 Ekim 1918'de Limni Adası'nda bulunan Mondros Limanı'nda Agamemnon adlı bir İngiliz zırhlısında Mondros Ateşkes Antlaşmasını imzalamıştır. Mondros Ateşkes Antlaşması sadece Osmanlı için I. Dünya Savaşını sona erdirmemiş aynı zamanda bütün Osmanlı topraklarının yazılı bir antlaşma ile belli bir hukuka dayandırılarak işgal edilmesine zemin hazırlamıştır. 25 maddeden oluşan bu antlaşmanın her bir maddesi başlı başına bir öneme sahiptir. Fakat bu antlaşmanın en ağır koşullarını 7. ve 24. maddeler oluşturmuştur. İtilaf Devletleri, düşündükleri işgallere zemin hazırlamak ve bunun hukuki alt yapısını oluşturmak için; 7. maddede "Müttefikler, emniyetlerini tehdit edecek vaziyet zuhurunda, herhangi sevkulceyş (stratejik) noktasını işgal hakkını haiz olacaklardır" diye belirtmişlerdir. (Türk İstiklâl Harbi, Mondros Mütarekesi ve Tatbikatı, I, 1962, s. 40-46; Bıyıklığlu- Ercan, 1992, s.38,41; Orbay, I, 1993, s.90-155). Bu madde sadece güvenliklerini tehdit altında gördükleri bir bölgeyi işgal etmeyi kapsıyor gibi görülse de, İtilaf Devletlerinin istedikleri zaman bir oldu-bittiyle her yeri işgal edebilecekleri anlamına gelmektedir. Nitekim de öyle olmuştur. Antlaşma imzalandıktan bir müddet sonra İngilizler 9 Kasım’da Musul'u işgal etmiştir (Jaeschke, 1970, s.3).

$\mathrm{Bu}$ işgaller devam ederken 13 Kasım'da ise İtilaf Devletlerinin donanması İstanbul'a gelmiştir (Türk İstiklâl Harbi, Mondros Mütarekesi ve Tatbikatı, I, 1962, s.47-49). İtilaf Devletlerinin donanması 5 yıl boyunca İstanbul'da kalacaktır. İtilaf kuvvetlerinin ilk işgal ettiği yerlerle yetinmeye niyetleri yoktu. Nitekim beklenen bu durum gerçekleşmiş, İngilizler ilk işgal ettiği Musul'a ek olarak 27 Aralık'ta Kilis'i, 1 Ocak'ta Antep'i, 31 Ocak'ta Osmaniye’yi işgal etmişlerdir (Türk İstiklal Harbi, Güney Cephesi, IV, 2009, s.49-60). Fransızlar ise Trakya'da bulunan demiryolunun büyük ve önemli istasyonları ile Afyon istasyonunu, Dörtyol, Mersin, Adana'yı işgal etmiştir. İtalyanlar antlaşma imzalandıktan sonra ilk etapta pasif kalmalarına rağmen Batı Anadolu bölgesinde Yunanistan'ın lehine gelişen siyasi paylaşımları gördükleri zaman Antalya, Kuşadası, Bodrum, Fethiye ve Marmaris'i işgal ederek, Konya ve Akşehir'e de birlikler yollamışlardır (Sofuoğlu, 2002, s. 618-619).

İtilaf Devletlerinin Anadolu'nun her yerini işgal etmeye başlamaları karşısında ve şartları çok ağır olan Mondros Ateşkes Antlaşmanın imzalanması karşısında kimse sessiz kalamazdı. Nitekim Anadolu'nun büyük bir kısmının düşman işgaline uğramasına birçok kesimden tepki gelmiştir. En büyük tepkiyi verenlerin başını Mustafa Kemal Paşa çekmiş ve I. Dünya Savaşında İtilaf Devletleri birliklerine karşı Çanakkale cephesinde başarılı mücadeleler vermiştir. Mustafa Kemal Paşa, bu antlaşma maddelerinin çok ağır koşullar içerdiğini belirterek bunun sonucunda yapılacak olan işgallerin ortaya çıkaracağı sorunların Türk milletinin başını çok ağrıtacağını söylemiştir. Bu sırada Mustafa Kemal Paşa Ahmet İzzet Paşa tarafından Yıldırım Orduları Grup Komutanlı̆̆ı'na atanmıştır. (Çankaya, 1995, s.22). Mustafa Kemal Paşa 31 Ekim 1918'de Limon Von Sanders'ten Yıldırım Orduları Grup Komutanlığını devralmıştır (Onar, 1991, s.1). 13 Kasım 1918 tarihinde Osmanlı Devleti’nin başkenti olan İstanbul İtilaf Devletleri tarafından işgal edilmiştir. 16 Kasım günü M. Kemal Paşa, Pera Palas Oteli'nde gazetecilere bir mülakat vermiş ve burada Mondros Ateşkes Antlaşması'nın siyasi bir yenilgi sonucunda imzalandığını belirtmiştir. Aynı zamanda manen, ilmen ve ahlaken kuvvetli olmak gerektiğinin belirtmiş, eğer bu meziyetler herhangi bir toplumda yer almazsa silahlı olarak en kuvvetli olmanın bir işe yaramayacağını söylemiştir (Çankaya, 1995, s.24). M. Kemal Paşa 18 Kasım 1918 tarihinde de Vakit gazetesine bir mülakat vermiş ve burada Meclis-i Mebusan'ın milleti temsil etmediğini belirterek, antlaşmanın nasıl uygulanacağı ve uygulanırken karşılaşılacak olan problemlerin nasıl çözüleceği hakkında görüşlerini belirtmiştir (Vakit, 18 Kasım 1918).

İtilaf Devletleri, işgalleri Anadolu'nun her tarafına yaymak için, Samsun'da bulunan Türklerin halen terhis olmadığını ve silahlarını kendilerine teslim etmediğini bahane göstererek Samsun'u işgal etme tehdidinde bulunmuştur (Budak, 1997, s.81-105). Ayrıca orada bulunan Müslüman Türklerin Hristiyanları katlettiğini de iddia etmişlerdir. Osmanlı Devleti, bölgede durumu araştırmak ve eğer İtilaf Devletlerinin iddia ettiği gibi bir 
durum varsa da orada önlem almak için bölgeye bir müfettiş gönderilmesine karar vermiştir (AltuncuoğluErdoğan, 2019, s.64). Mustafa Kemal Paşa, 9. Ordu Müfettişi olarak görevlendirilmiş ve 19 Mayıs 1919 tarihinde Samsun'a çıkmıştır (Atatürk'ün Samsuna Çıkışı ve Kurtuluş Savaşı'nın Başlatılmasına Dair Belgeler, 1999, s.79). Yunanlıların 15 Mayıs 1919'da İzmir’i işgal etmeleri üzerine, 20 Mayıs 1919 günü Samsun'dan Sadrazam'a ve Harbiye Nazırı'na bir telgraf çekmiştir. Bu telgrafta, vatan toprakları üzerinde bu ve benzeri işgallerin olmasını engellemek için, bir an önce gerekli tedbirlerin alınmasını istemiştir (Atatürk İle İlgili Arşiv Belgeleri (1911-1921 Tarihleri Arasina Ait 106 Belge), 1982, s.26).

İtilaf Devletlerinin daha önce işgal ettikleri yerlerde de tepkiler olmuşsa da İzmir' in Yunanlılar tarafından işgal edilmesi halk üzerinde bugüne kadar olmadığı bir şekilde büyük bir tesir uyandırmıştır. Buna bir neden olarak şu durum da gösterilebilir: Mondros Ateşkes Antlaşması maddelerinde İzmir ve çevresi ile ilgili hiçbir hüküm bulunmamasına rağmen, böyle önemli ve stratejik bir noktanın İtilaf Devletlerinin desteğiyle Türk toprakları üzerinde genişlemeye çalışan Yunanistan'ın işgaline bırakılması, Türk milletini çok gücendirmiştir. Nitekim İzmir demek Anadolu'nun Batı girişi demektir. Oraya hâkim olan Yunanistan sadece orada kalmayacak ve içeri doğru genişleyecektir (Sofuoğlu, 2002, s.624-625). İstanbul'da bulunan padişahın ve hükümetin düşman işgalleri karşısında bir şey yapmaması üzerine, Anadolu'nun her yerinde halk tarafından bulundukları bölgeyi düşman saldırısından korumak için Kuvayımilliye oluşturulmuştur. Kuvayımilliye; Türk Milli Mücadele döneminde, düşmana karşı savaşan milis kuvvetler olmuştur (Türk Silahlı Kuvvetleri Tarihi, TBMM Hükümeti Dönemi, IV, 1984, s.90-100).

Anadolu'nun işgal edilmesi halkta bir takım sosyo-kültürel problemleri ortaya çıkarmıştır. Bu durum sadece Türkler için değil bütün dünyada yaşayan uluslar içinde geçerli bir çıkarımdır. Halk, asırlarca üzerinde yaşadığı toprakların, yabancı güçler tarafından işgal edilmesi karşısında eskisinden daha güçlü bir şekilde o topraklara aidiyet bağı geliştirirler ve korumaya çalışırlar. Nitekim Kuvayımilliye bunun en somut örneğidir. Kuvayımilliye hareketi düşmanı işgal ettiği yerlerden atmanın yanı sıra halkta da birlik ve beraberliği sağlamış ve halktan her kesimi birbiri ile bütünleştirmiştir. Bu sayede Anadolu'nun önce Doğu ve Güney bölgeleri düşmandan temizlenmiş ve daha sonra ise bütün halk maddi-manevi her şeyiyle Batı bölgesini tamamen işgalden arındırmak için el birliği ile mücadele etmişlerdir.

TBMM, Mondros sonrası Anadolu'nun işgal edilme sürecinde, halkın da desteğiyle Doğu ve Güney cephesinde İtilaf Devletlerine karşı askeri alanda başarılı mücadeleler vermiştir. Takvimler 1921 yılını gösterdiğinde, Anadolu'nun doğusunda ve güneyinde düşman işgali durdurulmuş; doğu sinırları Kars Antlaşması, güney sınırları ise Ankara Antlaşması ile güvence altına alınmıştır. Anadolu'da devam eden ve işgal altında kalan tek yer ülkenin batısında kalan bölge olmuştur. Bu bölge Yunan işgali altındadır. Ege ve Trakya Yunanlıların, Çanakkale ve İstanbul Boğazları ise İtilaf Devletlerinin işgali altında bulunmaktaydı. Batı Cephesinde Yunanlılara karşı sırasıyla I. İnönü (10 Ocak 1922) ve II. İnönü (1 Nisan 1922) savaşı kazanılmıştır. Fakat 1020 Temmuz arasında Kütahya-Eskişehir Muharebeleri ile Yunanlılara karşısında bir mağlubiyet alınmış, bir ay sonra gerçekleşecek olan Sakarya Meydan Muharebesi'nde (23 Ağustos-13 Eylül) bu mağlubiyet telafi edilmiş ve Sakarya'da büyük bir zafer kazanılmıştır. 22 Ağostos-13 Eylül 1921 tarihinde yapılan Sakarya Meydan Muharebesi, Milli Mücadele Döneminin çok önemli bir safhasını teşkil etmiş ve dönüm noktası olarak kabul edilmiştir. Nitekim bu muharebe iki buçuk asra yakın devam eden Türk savunması artık sona ermiş ve Türkler taarruz pozisyonuna geçmişlerdir. Yunan kuvvetleri Türk askerleri tarafından Sakarya Nehrinin doğusunda durdurulmuş ve Eskişehir-Afyon hattının gerisine çekilmeye zorlanmıştır. Sakarya Meydan Muharebesi ile Yunanlılara büyük bir darbe vurulmuş fakat bu yeterli olmamıştır (Çınar-Yalçınkaya, 2009, s. 86). 


\section{Mudanya Ateşkes Antlaşması'na Götüren Zafer: Büyük Taarruz}

Mustafa Kemal Paşa, Sakarya Meydan Muharebesi'nden sonra 1921 yılının son aylarını da iyi değerlendirmiş ve bu süre zarfında artık Yunanlılara son darbeyi vurmanın vaktinin geldiğini düşünmüştür. Çünkü Sakarya Meydan Muharebesi ile Türk Ordusu taarruz pozisyonuna geçmiş ve bunun yanında Yunanlılardan da birçok stratejik noktaları geri almıştır. Mustafa Kemal Paşa 1922 yılına gelindiği zaman daha önce düşünmüş olduğu gibi Yunanlıları Anadolu'dan tamamen atmak için onlara karşı Büyük Taarruz'u yapma kararını vermiş ve bu süreci başlatmıştır. Bunun için 1921 yılında başlatmış olduğu askeri hazırlıkları, 1922 yllının Haziran ayı içerisinde hızlandırmıştır. Mustafa Kemal Paşa, bu ay içerisinde Eskişehir taraflarında bulunan Sarıköy'de İsmet Paşa ile görüşmüş ve gizli bir şekilde taarruzun hazırlıklarını başlatmıştır. (Goloğlu, 2010, s.305) Burada, Fevzi ve İsmet Paşalar ile taarruzun harekât planı çizmiş, ordunun nerede konaklayacağı ve hangi taraftan hücuma geçeceğini belirlemiştir (Yüceer, 2017, s.141).

Mustafa Kemal Paşa taarruz planını belirlerken bir yandan da birkaç ay önce ordunun ihtiyaçlarının giderilmesi için başlatmış olduğu hazırlıkları tamamlamaya çalışmıştır. Ordunun bütün eksiklikleri için Anadolu'da var olan küçük imalathaneleri kullanılmıştır. Mustafa Kemal Paşa, Milli Mücadele Dönemi’nde Konya'yı Batı Cephesi’nin ikmal merkezi olarak görmüş ve bu nedenle Konya'da yeni bir imalathane kurdurulmuştur (Semiz ve Toplu, 2017, s.254-283). Bu imalathanelerde sadece ordunun kullanacağı silah ve alet edevat yapılmamış, bunun yanında elbise dikme gibi birçok işler de yapılmıştır. Sadece bu imalathanelerde yapılan ve üretilenlerle yetinilmemiş daha önce Anadolu'yu işgal etmeye gelen İtilaf Devletlerinin ordusundan arta kalan askeri malzemeler de para karşılığında alınması için çalışmalar yapılmıştır. Daha önce Güney bölgesini işgal eden Fransız ve İtalyanlara karşı başarılı mücadeleler verildikten sonra onlar buralardan temizlenmiş ve onlarla antlaşma yapılmıştır. Bu antlaşma sayesinde o devletlerden yüklü miktarda silah ve cephane alınmıştır (Müderrisoğlu, 1990, s.504-510, 546-548, 557-558).

Bu esnada Rusya'dan da obüs topları, şarapnel, mermi gibi birçok silah, mühimmat ile para yardımı da alınmıştır. Rusya, yardım olarak 1920 yılında 21 Eylül-15 Ekim arasında toplam 2.815 adet İngiliz tüfeğiyle 1.885 sandık cephaneyi Trabzon'a yollamıştır. Ardından ise 500 adet daha İngiliz piyade tüfeğiyle 250 sandık cephane yardım olarak Giresun Alayı komutanı Topal Osman'a verilmiştir. Böylece, Rusya'dan Milli Mücadele Dönemi içerisinde 37.812 tüfek, 324 makineli tüfek, 44.587 kutu mermi, 66 top, 141.173 top mermisi alınmıştır. Rusya'dan ayrıca para yardımı da alınmıştır. 1920'de 1.809.412, 1921'de 5.781 .600 ve 1922 'de 2.714 .000 lira yardım alınmış ve bu yardımların toplam miktarı 10.305.012 lira olmuştur (Kılıç, 2016, s.127, 131, 136). Ayrıca dışarıdaki Müslümanlardan Ankara Hükümeti’ne gönderilen yardımları da unutmamak lazımdır. Hint Hilafet Komitesi, Anadolu'da ki Milli Mücadele için yardım kampanyası başlatmıştır. Özellikle Hindistan Müslümanları Anadolu’ya 125.000 İngiliz lirası yardım göndermişlerdir (Şahin, 2019, s.747). Bu yardımların çoğu Milli Mücadele'de kullanılmış ve arta kalanlar ise Cumhuriyet kurulduktan sonra vatanın imar sürecine maddi kaynak sağlamıştır. Yapılan bütün bu hazırlıklarla beraber, Anadolu'nun çeşitli yerlerinde işgal kuvvetlerinin bıraktığı ve Anadolu'daki imalathanelerde yeni yapılan bütün silahlar, hızlı bir şekilde Batı cephesine taşınmıştır

Bütün bu taarruz hazırlıklarını düşmana belli etmeden büyük bir gizlilik içinde yürütülmüştür. Türk ordusu, bütün cephaneyi taşıyan at ve katırların ayak seslerini Yunan askerlerine duyurmamak için onların ayaklarına keçeler bağlamışlardır. Cephaneler, bütün bu yorgunluk ve imkânsızlıklara rağmen kısa bir sürede o bölgenin en yükseği olan Kocatepe'ye intikal ettirilmiştir. O dönemin zor şartları altında gerçekleştirilen sadece bu gelişme başlı başına büyük bir başarıdır (Çevik, 2016, s.1570).

Mustafa Kemal Paşa, bütün bu hazırlıklar tamamlandıktan sonra, 4 Ağustos 1922'de TBMM'de bir konuşma yapmış ve ileri bir tarihte Yunanlılara karşı taarruz başlatılacağını Bakanlar Kuruluna bildirmiştir. Taarruz yapılacağını bildirmesine rağmen ne zaman yapılacağı hakkında net bir tarih ve bilgi vermemiştir. (Önder, 1972, s.256). Mustafa Kemal Paşa'nın, artık taarruzu başlatmak için savaş bölgesine, gizli bir şekilde gitmesi 
gerekiyordu. Bunun için trenle değil de kendi otomobiliyle gitmiş ve Ankara'dan ayrıldığını kimseye sezdirmeden Konya yolu üzerinden cepheye geçmiştir. Herkesin kendisini Ankara'da sanması için de 20 Ağustos 1922 günü Hâkimiyet-i Milliye gazetesine şu ilanı verdirmiştir: "Büyük Millet Meclisi Reisi Başkumandan Gazi Mustafa Kemal Paşa Hazretleri, Ağustos’un 21. Günü pazartesi günü öğleden sonra saat 4'te Çankaya'daki köşklerinde şehrimiz ricali siyasiyesine bir ziyafet keşide edeceklerdir. Ziyafette bütün sufera ve ricali siyasiye hazır bulunacaktır." (Hâkimiyet-i Milliye, 20 Ağustos 1922). Mustafa Kemal Paşa, aynı gazetenin 20-26 Ağustos 1922 tarihi arasında çıkan sayılarında da halkta bir endişeye mahal vermemek için düşmanla Aydın, Sarayköy yakınlarında ve Afyon cephesinde keşif çatışmalarının yapıldığı haberlerini yayınlatmıştır (Hâkimiyet-i Milliye, 20-26 Ağustos 1922).

Mustafa Kemal Paşa, 20 Ağustos günü Batı Cephesinde karargâh olarak kullanılan Akşehir'de idi. Batı Cephesi komutanına 26 Ağustos gününde Yunanlılara karşı taarruz başlatılacağını emretmiştir. Mustafa Kemal Paşa, Akşehir'de yine aynı gün ve ertesi günün gecesinde Başkumandan sıfatıyla diğer komutanlarla da görüşerek, taarruzun son durumunu değerlendirmiştir. Mustafa Kemal Paşa, burada yine bir hamle yapmış ve taarruzun dış ülkelerde hemen duyulmaması için, 25 Ağustos gününün akşamından itibaren Anadolu’nun dışarıyla bütün haberleşmesinin kesilmesini emretmiştir. Yine aynı günün sabahında, I. Ordu Komutanı tarafından taarruza geçileceği haberi bütün birliklere bildirilmiştir. Mustafa Kemal Paşa, 25 Ağustos gününün gecesinde, yarın sabah ordunun taarruza geçirileceği haberini hem Hükümete hem de TBMM’ye bildirmiştir (Çevik, 2016, s.1571).

26 Ağustos 1922 günü saat 05.30'da ilk topçu ateşiyle beraber Yunanlılara karşı taarruza başlanmıştır (Hâkimiyet-i Milliye, 27 Ağustos 1922). Gizli yürütülen taarruz hareketi 27 Ağustos'ta halka da duyurulmuş ve aynı gün TBMM'de 'Hükümetimizin Halk ve Memurlarımıza Beyannamesi' adı ile bir tebliğ yayınlanmıştır. Bu tebliğde kahraman askerlerin canla başla vatanın istikbalini kurtarmak için düşmanla savaştığı belirtilmiş, zaferin yakın olduğu ve maddi-manevi destek veren millet için güzel günlerin geldiği söylenmiştir (Hâkimiyeti Milliye, 27 Ağustos 1922). Mustafa Kemal Paşa, savaş sırasında asker ve halkın moralini yüksek tutmanın gerektiğini biliyordu. Taarruzu halka duyurması ve bir beyanname yayınlamasındaki amacının maddi manevi halk desteğini almak ve askerlere moral vermek olduğu söylenebilir.

Yunan ordusu asker, silah ve cephane bakımından Türk ordusundan belirgin bir şekilde üstün bir konumdaydı. Fakat bu üstünlügü Türk ordusu karşısında kullanamamışlar ve taarruz başlatıldıktan bir gün sonra gibi çok kısa bir süre içinde 27 Ağustos'ta hezimete uğramışlardır. Aynı gün Afyon Yunanlılardan alınmış ve Dumlupınar mevkiinde Yunanlılar kuşatılmıştır. Bu kuşatılma da Yunan Başkomutanı Trikopis dâhil olmak üzere birçok Yunan askeri esir edilmiştir (TBMM Zabıt Ceridesi, Dönem I, Cilt 23, 1960, s. 268271). Birkaç gün içinde savaş bölgesi binlerce ölü Yunan askerleriyle dolmuş, Yunanlıların gücü ve direnci iyice kırılarak, bölgeyi terk etmeye koyulmuşlardır. Mustafa Kemal Paşa, onlara kesin ve son darbeyi vurmak, Anadolu'dan tamamen kovmak için 30 Ağustos günü orduyu bizzat kendisi komuta ve sevk etmiş ve o gün gerçekleşen Başkomutanlık Meydan Muharebesi'nde Yunan kuvvetlerinin büyük bir kısmı etkisiz hale getirilmiştir (Türkmen, 2010, s.143). Mustafa Kemal Paşa bununla yetinmeyerek yurttan tüm düşmanların temizlenmesi için 1 Eylül'de "Ordular! İlk hedefiniz Akdeniz'dir, ileri!" emrini vererek, Türk askerlerini İzmir'e doğru yönlendirmiştir (Hâkimiyet-i Milliye, 2 Eylül 1922).

Yunanlılar, Büyük Taarruz hücumu sonrasında, bir daha toplanamamak üzere ağır ve büyük bir yenilgi almışlardır. Bu yenilgi üzerine Yunanlılar, baştan beri kendisini maddi olarak destekleyerek Türklere karşı kışkırtan İngiltere'ye, 2 Eylül 1922 tarihinde başvurarak, Türklerle barış yapmalarına arabulucu olmasını istemiştir. İngiltere, Yunanistan'ın ateşkes isteğine hemen cevap vermeyerek, Yunan yenilgisinin kendilerince bir süre herkesten gizlemeye çalışmışlardır. İngiltere, Yunanlıların Türkler karşısında yenilgilerinin devam etmesi üzerine, artık Yunan ordusunun bir daha toplanamayacağını anlamış ve onların ateşkes isteğini 4 Eylül 1922'de önce Türklere değil de diğer müttefik devletlere bildirmiştir (Akın, 2002, s.219). 
Bütün bu süreçler devam ederken Türk ordusu savaşı bırakmamış, köy köy Yunanlıları takip ederek ve buraları kurtararak İzmir'e doğru ilerlemeye başlamıştır. Burada şu önemli konuya dikkat çekmek lazımdır: Türk uçakları savaşın devam ettiği günlerde, savaş bölgesine Rumca ve Türkçe yazılmış beyannameler atmıştır. Rumca beyanname ile Yunan askerlerine, Türkçe beyanname ile bölgede yaşayan Türk halkına hitap edilmiştir. Rumca beyannamede; bütün Yunan askerlerinin mağlup olarak topu tüfeği bırakarak kaçtığı, kalan askerlerin de etrafını sarıldığından bahsedilerek, eğer teslim olurlarsa sefalet ve açlık içinde ölmeyecekleri belirtilmiştir. Türkçe beyannamede ise; Türk halkının artık güven ve emniyette olduğu, Yunan askerlerinin yenilerek kaçmaya mecbur bırakıldığından bahsedilerek, düşmanın kaçarken köyleri yakmaya çalıştığı, eğer bunlar görülürse buna müsaade etmemeleri istenmiş, Türk askerlerinin bir gün içinde yardıma geleceği söylenmiştir (Hâkimiyet-i Milliye, 4 Eylül 1922).

İngiltere'nin önderliğinde Batılı Devletler, Yunanistan'ın ateşkes isteğini 7 Eylül günü Ankara’ya iletmiştir. Ancak Ankara Hükümeti zaman kazanmak ve bu süre zarfinda Anadolu’yu tamamen Yunanlılardan temizlemek amacı güttüğü için, bu ateşkes isteğine olumlu-olumsuz bir cevap vermemiş ve beklemiştir. Türk Ordusu, 9 Eylül 1922'de İzmir'e girmiş, 11 Eylül'de Bursa Yunan işgalinden kurtarılmış ve akabinde İstanbul, Boğazlar ve Doğu Trakya'yı da tamamen düşmandan arındırmak için harekete geçilmiştir (Tarih IV, Türkiye Cumhuriyeti, 1931, s.121-123; Kurtcephe vd. 1999, s.317; Peyâm-1 Sabah, 9 Eylül 1922). 18 Eylül 1922'de Milli Mücadele'nin son kurşunu Bandırma-Erdek arasında atılmış ve bugün aynı yerde o günün anısına dikilmiş Ay-Yıldız Tepe adıyla bir anıt yer almaktadır. Doğrudan Genelkurmaya bağlı Kocaeli Grubu ile III. Kolorduya bağlı 61. Alay’n askerleri tarafından Erdek kurtarılmıştır. Böylece Yunan esirleri dışında Anadolu'da hiçbir Yunan askeri kalmamıştır. Bu son çarpışmada 8'i subay olmak üzere 73 şehit verilmiştir. (Çevik, 2016, s.15841585).

Böylece üç yıldır devam eden Milli Mücadele'nin silahlı safhası artık sona ermiştir. Türklerin Yunanlılar karşısındaki zaferi Anadolu'nun her tarafında sevinçle karşılanmıştır. Ankara'da Cuma Namazı kılındıktan sonra, burada bütün halk toplanmış ve hep birlikte 'Amin' sesleri her tarafta yankılanarak dualar etmişlerdir. Dua edildikten sonra da Ankara Mebusu Hacı Mustafa Efendi bir konuşma yapmış ve ardından şükür kurbanları kesilmiştir (Hâkimiyet-i Milliye, 9 Eylül 1922).

Türklerin bu büyük zaferi karşısında, İtilaf Devletleri Türk askerlerinin daha da ilerlemesinden çekinmişlerdir. Bundan dolayı Mustafa Kemal Paşa İzmir'de bulunduğu sırada kendiyle konuşmaya gelen İtilaf Devletleri Donanma Komutanı İngiliz Amiral general Pelle ve Türk dostu olarak bilinen Fransız devlet adamı Franklin Boullion ile bir görüşme yapmıştır (TBMM Zabit Ceridesi, Dönem I, Cilt 23, 1960, s.275-276; Sürmeli, 2007, s.52). Bu kişiler, Mustafa Kemal Paşa'dan Türk askerlerinin tarafsız bölge olarak kabul edilen, İstanbul ve Çanakkale bölgesine girmemeleri isteğinde bulunmuşlardır. Mustafa Kemal Paşa, İstanbul ve Çanakkale bölgesinin sadece kendilerinin tek taraflı olarak tarafsız bölge ilan edip oraya Türk askerinin girmemesi isteklerine karşı sert bir tavır takınarak böyle bir bölgeyi tanımadığını ifade etmiştir. Mustafa Kemal Paşa akabinde iki nota vermiş ve İtilaf Devletlerinin derhal askeri harekâtlarını durdurması ve Yunanlıların 1914 yılından önceki sınırlarına çekilmesi şartıyla, Türklerin masada bir ateşkes anlaşmasına oturacağını bildirmiştir (TBMM Zabıt Ceridesi, Dönem I, Cilt 23, 1960, s.275-277).

Yunanistan'ın en büyük destekçisi olan ve Batı Anadolu'nun onların olması için diğer İtilaf Devletlerini de ikna eden İngiltere, Türklerin bu zafer sonucunda durmayarak daha ileriye doğru gideceğini tahmin etmesi güç değildi. Çünkü gözlerini ileriye diken Türklerin Çanakkale ile İstanbul Boğazına doğru yürümesi ve oraları ellerine geçirmeleri an meselesiydi. İngiltere bu durumda bile Türk zaferini kabul etmemek için her yolu denemek için gayret etmişlerdir. Yunanlılara asker takviyesi yapmak ve onları tekrar Türklere karşı savaşa davam ettirme planları bile yapmışlardır. Hatta İngiltere, Yunanlılara tekrar asker desteği vermek için sömürgelerinden destek istemiş fakat sömürgelerinden Yeni Zelanda haricinde hiçbirinden olumlu cevap alamamıştır (Şimşir, 1984, s.530-545; Yeşilbursa, 2019, s.1018)). İngiltere'nin savaş yanlısı bu tutumu ve savaşı 
devam ettirme arzusu sadece sömürgelerinden değil hem kendi kamuoyundan hem de müttefikleri olan Fransa ve İtalyanlar tarafından da olumsuz karşılanmıştır. Başbakan Lord Curzon, bütün bu hengâme devam ederken müttefiklerinin gönlünü almak ve ilişkileri daha da iyileştirmek için 19 Eylül'de Paris'e giderek, orada Fransa Başbakanı Poincare ve İtalyan Büyükelçi Count Sforza ile görüşmüş ve onlarla aradaki bağı koparmamaya çalı̧̧ıı̧̧ır (Aralov, 1985, s.150-155). Burada Lord Curzon'un pragmatist davrandığı göze çarpmaktadır. Çünkü Büyük Taarruz sonrasında bir antlaşma yapılıncaya kadar barış mı yapılacağı yoksa savaşa mı devam edileceği bir süre belirsizliğini korumuştur. İngiltere her ne kadar savaşı devam ettirme arzusu gütmekteyse de hem kendi kamuoyu hem de müttefikleri ve onların egemenliği altında bulunan halk bu savaşın bir an önce bitmesi taraftarıydı. O nedenle Lord Curzon, müttefikleri ile aralarında oluşan soğukluğu bitirmek ve tekrar onları bir hedef doğrultusunda bir araya getirmek için çeşitli stratejik hamleler yapmıştır.

Gerek Yunan ordusunun bir daha toplanamamak üzerine bir büyük darbe alması gerekse de İngiltere'nin artık bu savaşı devam ettiremeyeceğini gören Mustafa Kemal Paşa, artık Büyük Taarruz’un askeri safhasının tamamlandığını düşünmüş ve 18 Eylül'de savaşın özetini anlattığı şu beyannameyi yayınlamıştır: "Büyük Türk milleti, Ordularımızın kabiliyet ve kudreti düşmanlarımıza dehşet, dostlarımıza emniyet verecek bir kemal ile tezahür etti. Millet orduları on dört gün zarfında büyük bir düşman ordusunu imha ettiler. Dört yüz kilometrelik fasılasız bir takip yaptılar. Anadolu'daki bütün memalik-i müstevliyemizi istirdat eylediler. Büyük zafer münhasıran senin eserindir. Çünkü İmir'imizi ihtirasat-ı siyasiye neticesinde adeta memnunen düşmana teslim eden heyetlerle milletin hiçbir münasebeti yok idi. Bursa'mızı istilâ eden Yunan kuvvetleri ise ancak imparatorluğun askeri teşkilâtiyle tevhid-i amâl ve tevhid-i harekât ederek muvaffak olmuşlardı. Vatanın halâsı milletin rey ve idaresi kendi mukadderatı üzerinde bilâkaydüşart hâkim olduğu zaman başlamış ve ancak milletin vicdanından doğan ordularla müsbet ve kati neticelere ermiştir. Büyük ve Necip Türk Milleti, Anadolu'nun halâsı zaferini tebrik ederken sana İzmir'den, Bursa'dan, Akdeniz ufuklarından ordularının selâmın da takdim ediyorum." (Hâkimiyet-i Milliye, 18 Eylül 1922). Burada Mustafa Kemal Paşa, orduyu tebrik ederken üstü kapalı olarak da ileride demokrasiye dayalı bir sistemi tasarladığı görülmektedir. Çünkü 'Vatanın halâsı milletin rey ve idaresi kendi mukadderatı üzerinde bilâkaydüşart hâkim olduğu zaman başlamış' cümlesinde, Anadolu'nun kurtuluşunun milletin kendi iradesi ile seçtiği kişilerin TBMM'de söz sahibi olması sonucunda neticelendiğine dair atıflar vardır.

Türk ordusunun büyük zaferinin yankıları İtilaf devletleri üzerinde devam ederken, İzmir ve Bursa’nın da Türkler tarafından ele geçirilmesi özellikle İngiltere’yi bir endişeye sevk etmiştir. İngiltere’nin, bundan sonra Türk ordusunun Boğazlar üzerine yürüyeceğini tahmin etmesi güç değildi. General Harrington, Türklerin Çanakkale ve İstanbul Boğazına ilerlememeleri için 26 Eylül'de TBMM'nin İstanbul temsilcisine başvurmuş ve Türklerin Çanakkale için Biga'nın batısından, İstanbul için ise Erenköy'ün batısından çekilmelerini rica etmiştir. Türkler ile aralarında bir ateşkes antlaşması yapılıncaya kadar, Türk askerlerinin bu tarafsız bölgelerden uzak kalmalarını istemiştir (Sürmeli, 2007, s.51). Mustafa Kemal Paşa, burada usta bir siyasetçi gibi mahir bir politika izlediği göze çarpmaktadır. Böylelikle Osmanlı Devletinin İtilaf Devletleri ile Boğazlar üzerinde yapmış olduğu anlaşmayı üstü kapalı olarak reddetmiş ve Ankara hükümetinin Boğazlar ile ilgili bir antlaşma imzalamadığını belirtmiştir. Harrington'a bu zamana kadar o bölgenin tarafsız bölge olduğundan haberdar olmadığını ve buranın tarafsız bölge olarak TBMM tarafından kararlaştırılmadığını belirtmiştir. Türk askerinin o bölgelere Yunan askerlerini takip etmek için girdiğini çünkü o yerlerde Yunanlıların halka büyük zulüm yaptığını söylemiştir. Hatta M. Kemal Paşa, 25 Eylül'de Yunan donanmasının İstanbul'a demir atarak, İstanbul ile Çanakkale arasında neredeyse Britanya kıtaları genişliğinde büyük yıkım ve katliamlar yaptığını dile getirmiştir (Sürmeli, 2007, s.52-53). Harrington, Mustafa Kemal'e Yunanlıların hiçbir zaman o bölgede askeri amaçlı yıkımlar yapmadığını ve bu konuda oralarda inceleme yaptırdığını ifade etmiştir. Harrington, tekrardan Türklerin Çanakkale ve İstanbul boğazlarını tehlikeye atacak girişimlerden uzak durmalarını rica ederek, İngiltere'den yeni askerler geldiğini ve bu askerlerin savaş için değil barış için kullanılacağını belirtmiştir (Hâkimiyet-i Milliye, 20 Ağustos 1922- 1 Eylül 1922; Karacan, 1971, s.28-32). 
Burada şu hususu da vurgulamak gerekir ki, İngiltere'nin savaş yanlısı tutumu sadece kendi ülkesinde değil müttefiki olduğu diğer İtilaf Devletleri içerisinde de tasvip edilmemektedir. Türklerin vatanlarını savunmak için vermiş oldukları bu büyük başarı, Fransız kamuoyunda Türklerin zaferi olarak yer almıştır. Hatta Fransız basınında, İngiltere Başbakanı Lloyd George'nin Yunan tutuculuğu yaptığı ve onları Türklere karşı kışkırtması ile asıl mağlup olanın Yunanistan değil de İngiltere olduğu yazılmıştır (Akyüz, 1988, s.298-301). Artık Türklerin ebediyete kadar Asya ve Avrupa'dan atılamayacağını tüm dünyaya göstermiş oldukları belirtilmiştir. Nitekim gerek Büyük Taarruz sonrasında gerekse de neredeyse bir buçuk ay sonra imzalanacak olan ateşkes antlaşmasına giden süreçte Türk askerleri, İngilizlerin her türlü stratejik oyun ve planlarına karşı, kararlı bir şekilde tarafsız bölge ilan edilen yerde ilerlemişlerdir. Türkler, bu haklı mücadelesine, İtilaf Devletlerinin İngiltere'den sonra gelen en büyük askeri gücü Fransa ile İtalya'yı da inandırmışlar, hem onların desteğini kazanmışlar hem de onların Türkler aleyhine bir strateji geliştirmesinin önünü kesmişlerdir. Bunun sonucunda Fransa ve İtalyanlar da dolaylı olarak İngiltere'nin stratejik kurnazlık yapma tavrı karşısında yer almış ve artık Türk-Yunan savaşının barış̧̧l yollarla çözülmesi yolundaki düşüncelerini sesli bir biçimde dile getirmişlerdir (Üçüncü, 2012, s.435-441). Bu gelişme bize Türkler’in sadece askeri olarak savaşı kazanmadığını aynı zamanda ise uygulamış oldukları stratejik taktikler ile düşman safında olan Fransa ve İtalya'yı da yanına çektiklerini göstermektedir. Mustafa Kemal Paşa'nın uyguladığı bu taktikler hiç şüphesiz bir müddet sonra imzalanacak olan ateşkes antlaşması sırasında, masada Türklerin elini güçlendirmiştir.

Bütün bu süreçler devam ederken İtilaf devletleri 19-23 Eylül tarihleri arasında Paris'te kendi aralarında bir konferans yapmışlar ve hemen akabinde 23 Eylül'de Mudanya'da generaller seviyesinde temsil edilecek bir ateşkes antlaşmasının toplanılmasını istemişlerdir (Sürmeli, 2007, s.52,53). Bu isteği TBMM'ye bir nota ile iletmişlerdir. Müttefik devletlerin generalleri Mustafa Kemal Paşa'nın ateşkes antlaşması imzalamasını istiyorlardı. İtilaf Devletleri, eğer Türkler barış görüşmelerinin devam ettiği süre zarfında, tarafsız kabul edilen bölgeleri işgal etmezlerse, azınlıkların güvenliklerini sağlarlarsa Meriç Nehri ve Edirne’ye kadar olan Trakya topraklarının Türkiye’ye verilmesini kabul edeceklerini bildirmişlerdir. Bütün bunlar sağlanırsa ve bir barış antlaşması imzalanırsa, antlaşmanın yürürlüğe girdiği tarihten itibaren Türkiye'nin Milletler Cemiyeti’ne girmesi için destek vereceklerini ve bütün askeri birliklerini İstanbul'dan çekeceklerini de taahhüt etmişlerdir. Akabinde ise İtilaf Devletlerini temsil etmek için özel yetkilerle donatılan Fransız temsilcisi Franklin Boullion 28 Eylül'de İzmir'e gelmiş, Mustafa Kemal Paşa ile görüşerek Mudanya'da bir konferansın yapılmasına karar vermişlerdir (Hâkimiyet-i Milliye, 12 Ekim 1922; Yeşilbursa, 2019, s. 1019-1020). Burada İtilaf Devletlerinin özellikle hiçbir şekilde Türklerin barış antlaşması imzalanana kadar Boğazlar'ı geçmemesini istemesi durumu düşündürücüdür. İtilaf Devletleri Osmanlı Devleti ile 10 Ağustos 1920'de imzaladıkları Sevr Antlaşması'nda, Boğazlar ile ilgili hükmün devam etmesi için çabaladıkları görülmektedir. Çünkü Sevr Antlaşması gereği, Boğazları kontrol eden bir komisyon kurulacak, Boğazlar bütün devletlere açık bırakılacak ve herhangi bir savaş esnasında bile savaş gemilerinin geçirilmesine izin verilecektir. Bu da göstermektedir ki İtilaf Devletleri artık Anadolu'dan toprak koparmaktan çok orada ekonomik çıarlarını korumak siyasetinin devam ettirmeye çalışmışlardır.

\section{Mudanya Ateşkes Antlaşmasının İmzalanması Sürecinde Yaşanan Gelişmeler}

Mustafa Kemal Paşa'nın Mudanya'da yapılacak olan görüşmeleri kabul etmesi üzerine birkaç önemli değerlendirme yapmanın çalışma açısından önemli olacağı kanaatindeyiz. Mustafa Kemal Paşa'nın askeri ve siyasi tavrını hem Büyük Taarruz sırasında hem de Taarruzdan sonra yapılacak olan bir antlaşma öncesinde çok yerinde ve uygun zamanlarda ortaya koyduğunu görmekteyiz. Hem kendisini hem de ordusunu büyük bir zafer sarhoşluğu içerisine sokmamış, emin adımlarla kafasında belirlediği noktalara kadar ilerlemiş ve oraları almıştır. Ayrıca Mustafa Kemal Paşa gerek Yunanistan'ın gerekse de İngiltere'nin tahrik edici provokasyonlarına kanmamış ve İngiltere'yi kızdırmadan çeşitli taktikler izlemiştir. Özellikle İtilaf 
Devletlerinin ve bilhassa da İngiltere'nin Boğazlar üzerinde hassas davrandığını bildiği için, bu konuda kışkırtıcı adım atmaktan uzak durmuş ve askerlerini meydana gelebilecek çatışmalardan men etmiştir. Barış yanlışı bir tutum sergilediğini her platformda dile getirmiş ve bu tavrını İtilaf Devletleri temsilcileri ile olan görüşmelerinde de yansıtmıştır. Zaten bütün bu gelişmeler TBMM’nin İtilaf Devletleri nezdinde hukuksal olarak tanınmasının önünü açmış ve onlarla birlikte eşit koşullarda masaya oturmasına zemin hazırlamıştır.

Mustafa Kemal Paşa, generaller seviyesinde temsil edilecek olan ve Mudanya'da yapılması kararlaştırılan ateşkes görüşmelerini kabul etmiştir. Bundan sonra artık askeri alanda binlerce şehit verilerek kazanılan bu mücadeleyi masa başında taçlandıracak ve dökülen kanların karşılı̆̆ını her damlasına kadar alacak, dirayetli birinin konferansa seçilmesi gerekliydi. Bu konferans generaller seviyesinde temsil edileceği için rütbe olarak Mustafa Kemal Paşa’nın katılması uygun olmazdı. Çünkü o hem başkomutan hem de askeri rütbelerin en büyüğü olan mareşal unvanına sahipti. Mustafa Kemal Paşa'nın aklından İsmet (İnönü) Paşa geçmekteydi. Mustafa Kemal Paşa'nın İsmet Paşa'yı düşünmesinin nedenini iki maddede sıralayabiliriz. Bunlardan ilki Mustafa Kemal Paşa'nın en güvendiği isimlerin başında yer almaktaydı. İkincisi ise İsmet Paşa Batı Cephesi Komutanı olarak Yunanlılara karşı Ege'de çok başarılı bir şekilde mücadele etmiş olmasıydı. Bütün bunların ötesindeki en önemli şey ise Mustafa Kemal Paşa'nın, Milli Mücadele’nin en başından beri süreci İsmet Paşa'yla beraber süreci yönetmesidir. Mustafa Kemal Paşa, İsmet Paşa'nın Mudanya'da yapılacak olan ateşkes antlaşmasında Türk milletinin çıkarlarını sonuna kadar koruyacağından ve bu konuda dirayetli ve başarılı olacağından da emindi. Mustafa Kemal Paşa, bu ateşkes antlaşmasının imzalanması için İsmet Paşa'yı görevlendirmesini Nutuk'ta şöyle anlatmıştır:

“...Konferansin toplanmasından evvel, Yunan kitalarının, İtilaf devletleri kumandanlarının çizecekleri bir hattın gerisine çekilmesi için, İtilaf devletlerinin nüfuzunu kullanacağı vaat olunmakta ve bu konuda görüşülmek üzere Mudanya veya İzmit'te bir toplantı yapılması teklif edilmekte idi. 29 Eylül 1922 tarihinde, bu notaya verdiğim kısa bir cevapta, Mudanya Konferansi'nı kabul ettiğimi bildirdim. Fakat, Meriç nehrine kadar Trakya'nın derhal bize iadesini talep ettim. 3 Teşrinievvel'de [3 Ekim'de] toplanmasının münasip olacağını söylediğim Mudanya Konferansı'na, Başkumandanlık namına fevkalade salahiyete sahip olmak üzere Batı Cephesi Orduları Kumandanı İsmet Paşa'yı delege tayin ettiğimi tebliğ ettim...” (Nutuk, 2015, s.517,518).

Ateşkes antlaşmasında Türk tarafının kim tarafından temsil edileceği konusu kararlaştırıldıktan sonra görüşmenin yapılacağı yer hakkında bilgi vermek gerekli olduğunu düşünmekteyiz. Çünkü Mudanya, İtilaf Devletleri tarafından rastgele seçilmiş bir yer değildir. Mudanya stratejik olarak önemli bir konumda bulunmaktaydı. Mudanya'nın Marmara Denizi kıyısında yer alması ve İstanbul-Boğazlara da çok uzak bir konumda olmaması seçilmesinde önemli bir etken olmuştur. İtilaf Devletleri sırtlarının bir tarafını karaya dayarken öteki tarafını ise denize dayamaktaydılar.

Bunun yanında Mudanya'da yapılacak olan konferansa ev sahipliği yapan konak hakkında da bilgi vermek yararlı olacaktır. Bu konak 19. yüzyılda, Rus kereste tüccarı Aleksandr Ganyanof tarafından inşa ettirilmiştir. Konak, toplamda $800 \mathrm{~m}^{2}$ olan arsanın $400 \mathrm{~m}^{2}$ alanını kaplamaktadır (Alper, 2013, s.30-31). Toplamda iki katlıdır ve çevrede bulunan en gözde konaklardan birisidir. Konağın ön kısmı ana cepheye arka kısmı ise denize bakmaktadır. Ana cepheye bakan kısımda hoş bir cumba, deniz tarafına bakan kısımda ise denizin seyredilebileceği küçük bir balkon vardı. Konağın girişinde birkaç basamak merdiven vardı ve bu merdivenlerden geçilerek konağa giriliyordu. Konağın içine girildiğinde hoş bir sofa konukları karşılıyordu. Sofanın sağında ve solunda ise odalar vardı. Görüşmelerin yapılacağı salon binanın girişinde sol tarafta bulunuyordu. Bu oda ilk etapta tek ve küçük bir oda olarak inşa edilmişken, toplantı için yan tarafındaki odanın duvarı kırılarak birleştirilmiş ve büyütülmüştür (Ar1, 2008, s. 98). Konak adeta görüşmeler için tekrardan dizayn edilerek hazır hale getirilmiştir. Konağın deniz tarafına bakan yönünde balkon bulunması İtilaf 
Devletlerinin çok işine yaramıştır. Çünkü İtilaf Devletleri gemilerinin bazıları konağa çok uzak olmayan bir mesafeye demir atmışlar ve kendi aralarında daha önce belirlemiş oldukları şifreli hareketler ile konakla deniz arasında iletişim kurmuşlardır.

Nihayet beklenen görüşmeler, 3 Ekim 1922'de saat 15.15’te başlamıştır. Türkler Batı cephesinde Yunanlılara karşı savaşmasına rağmen antlaşma için masaya Yunanlılar değil de İtilaf Devletleri oturmuşlardır. Bu da göstermektedir ki Türkler görünüşte Yunanlılara karşı fakat gerçekte ise bütün İtilaf Devletleriyle savaşmıştır. TBMM, İsmet Paşa haricinde ayrıca Fevzi Paşa ve Refet Paşaları Mudanya’ya göndermiş ama bu paşalar doğrudan görüşmelere katılmamış ve ateşkes imzalanıncaya kadar orada bulunmuşlardır. Görüşmelerde Türk delegeleri olarak Batı Cephesi Kurmay Başkanı Asım (Gündüz) Paşa, Kurmay Yarbay Tevfik Bıyıklığlu, Binbaşı Seyfi (Düzgören) Bey, Kızılay İkinci Başkanı Hamit Bey de yer almış ve bunların yanında iki yazman görevlendirilmiştir. İtilaf Devletleri adına ise İngiltere'yi general Harrington, Fransa'yı general Charpy ve İtalya'yı da general Monbelli temsil etmiştir. Yunanistan bir temsilci belirlemesine rağmen bu temsilcilerden general Mazarakis ve Albay Sariyanis, görüşmelere doğrudan katılmamış ve görüşmeyi Mudanya yakınlarında bulunan bir İngiliz gemisinden izlemişlerdir (TBMM Zabıt Ceridesi, Dönem I, Cilt 23, 1960, s.349-353; İnönü, II, 1987, s.25-40; Turan, 2003, s.49).

Konferansın başlarında konferansa kimin başkanlık yapacağı belli değildi. İsmet Paşa, ev sahibi olması hasebiyle konferansa gelen heyeti tek tek karşılamış ve onları görüşmelerin yapılacağı büyük salona götürmüştür. İsmet Paşa generallere masada yer göstermiş, kendi sağına general Harrington'u soluna general Monbelli'yi, karşı tarafına ise general Charpy'i oturtmuştur. İsmet Paşa generallere kendisinin yer göstermesini generallerin yadırgadığını ve içlerinden birinin konferansa başkanlık yapacağını sandıklarını söylemiştir (Alper, 2013, s. 33). Böylece toplantıya kimin başkanlık yapacağı meselesi kendiliğinden ortadan kalkmıştır. Generaller İsmet Paşa'nın konferansa başkanlık etmesine ses çıarmayarak, kabul etmişlerdir Görüldügüü üzere Ankara Hükümeti üç büyük devlet İngiltere, Fransa ve İtalya ile eşit şartlar çerçevesinde masaya oturmuş ve onlar tarafından hukuksal olarak tanınmıştır.

Salona iki tane büyük masa koyulmuştur. Birisi temsilcilere ötekisi ise kâtiplere ayrılmıştır. General Harrington, daha önce hiç İsmet Paşayla karşılaşmamış ve daha görüşmelerin başında Başbakanı olan Lord Curzon'a İsmet Paşanın kişisel özelliklerinden bahsettiği bir telgraf çekmiştir. Bu telgrafta; İsmet Paşanın genç biri olduğu, dikkati çeken herhangi bir özelliğini görmediğini, çok az konuştuğundan ve bazı hallerde bir kusur bazı hallerde de üstün olmasını sağlayan sağırlı̆ından bahsetmiştir. Görüşmeler başladığında Yunanistan'da Krala karşı askeri darbe başlatıldığı için Yunan temsilcisi görüşmelere katılmamıştır. İsmet Paşa, heyete madem Yunan temsilcisi yoktur, biz aramızda bir sonuca varalım zaten onlar bunu kabul etmek zorunda kalacaklardır demiştir (Başyiğit, 2007, s.180,181). İsmet Paşa'nın bu sözünde gizli bir nükte olduğu gözden kaçmamaktadır. Çünkü Yunanlılar İtilaf Devletlerinin özellikle de İngiltere’nin yardımları ile üç yıla yakın bir süre Anadolu'nun Batı bölgesini talan etmiş, maddi kayıpların yanı sıra yetişmiş insan gücünün de savaşta ölmesine neden olmuşlardır. İtilaf Devletlerinin kabul edeceği bir antlaşma Yunanistan tarafından da kabul edilecektir.

Kaynaklarda genel olarak Yunanistan'da askeri darbe başlatıldığı için Yunan temsilcilerinin görüşmeye katılmadıkları yönünde bilgiler yer almasına rağmen Karacan, bunu farklı bir sebebe dayandırmıştır. Karacan’a göre; Yunan temsilcileri deniz yolculuğu sırasında Pire ve Mudanya arasında firtınaya yakalandıkları için konferansın ilk gününe katılamamışlar ancak ikinci gün öğleden sonra Kızılhaç’a ait bir posta vapuruyla konferansa yetiştirilmişlerdir. Bundan dolayı Yunan general Mazarakis o sırada Yunanistan’ı değil de Yunan delegelerini temsil etmiştir (Karacan, 1971, s.36-37). Zaten Mustafa Kemal Paşa da Nutuk'ta Mudanya görüşmelerinin İsmet Paşa'nın riyaseti altında başladığını belirtmiş, İngiltere Delegesi general Harrington, Fransa Delegesi general Charpy, İtalya Delegesi general Monbelli'nin katıldığını söylemiş̧tir (Nutuk, 2015, s.518). Mustafa Kemal Paşa'nın Yunan delegelerinden hiç bahsetmediği görülmektedir. 
Antlaşma süreci boyunca general Harrington, kendini ve ülkesi İngiltere’yi Türk zaferi karşısında mağlup göstermemeye gayret etmiştir. Bu nedenle görüşmeleri kendisinin sunmuş olduğu 10 maddelik bir gündem maddesi ile tartışmaya açllmıştır. 10 maddelik bu açlış metninde, Türklerin dikkatini üç madde celp etmiş ve Türkler daha çok bu maddeler üzerine yoğunlaşmıştır. Burada, Doğu Trakya’nın Yunanlılar tarafından tahliye edilmesine karar verilmiş ama buranın Türklere verilmesi gündeme getirilmemiştir. Yunanlıların, tahliye edecekleri yerlerin tekrar müttefikler tarafından işgal edilmesi istenmiştir. Meriç nehrinin batısında yer alan ve Edirne’nin mahallesi olan Karaağaç'in geleceği hakkında hiç bahsedilmemiştir (Aydemir, III, 2016, s.35-36). $\mathrm{Bu}$ üç madde ilerleyen günlerde de konferansın gündemini meşgul etmiş ve konferans bunlar üzerinde şekillenmiştir.

Hem Türklerin hem de İtilaf Devletlerinin istediklerini alma konusunda ısrarcı tavırları, görüşmelerin daha ilk günden itibaren hararetli ve zorlu geçeceğini göstermiştir. İsmet Paşa'nın, görüşmenin ilk başlarında heyetlere, Yunan askeri kuvvetlerinin Meriç nehrinin soluna çekilmesini istediklerini belirttiği sırada, Yunan temsilcisi General Mazarakis bu isteğe şiddetle karşı çıkmıştır. Yeri gelmişken şunu hatırlatmak gerekir ki görüşme sırasında Yunan temsilcisinin sanki savaşı kazanmışlar gibi davranma tavırları, görüşmelerin uzamasına ve yer yer sıkıntılı süreçlerin yaşanmasına neden olmuştur. İsmet Paşa'nın Yunan askeri kuvvetlerinin Meriç nehrinin soluna çekilmesi isteğini Yunan temsilcisinin yanı sıra heyette bulunan diğer İtilaf Devletleri temsilcileri de hemen kabul etmemişlerdir (Başyiğit, 2007, s.182).

Konferansın üçüncü gününde, Generaller, Türklerin Doğu Trakya’ya geçirilecek olan jandarma ve memur sayılarında yapmış oldukları ısrardan ve bu harbin sona erdirilmesi kararını kabul etmişlerdir. Mustafa Kemal Paşa bunun yanında Doğu Trakya'nın hem Yunanlılardan hem de diğer müttefikler tarafından tamamen boşaltılarak işgalden arındırılması isteğini İsmet Paşa'ya bildirmiştir. Hatta Mustafa Kemal Paşa, İsmet Paşa'ya bu istek kabul edilmezse 6-7 Ekim'de derhal İstanbul'a dönüş talimatını vermiştir (Aydemir, III, 2016, s.37). Bu temsilciler, bu kararı tek başlarına veremeyeceklerini ve hükümetlerine bildirmeleri gerektiğini söylemiştir. Bundan dolayı 5 Ekim 1922'de görüşmeler kesilmiştir (Başyiğit, 2007, s.182).

Görüşmelerin kesilmesi ve herhangi bir karar birliğine varılamamasında özellikle İngiliz temsilci general Harrington'un takındığı tutumun da sebep olduğu görülmektedir. Çünkü Harrington’un, Türklerin kazandığı büyük zaferi görmezden gelmesi sanki Türkler savaşta yenilmiş gibi bir tutumla olaylara yaklaşması görüşmeleri bir çıkmaza sokmuştur. Harrington, Türk istekleri karşısında hep sert bir tavır takınmış ve işin içinden çıamayacağı zamanda İngilizlerin hem askeri hem donanma gücü olarak Türklerden çok üstün bir konumda olduğunu belirterek, üstü kapalı olarak Türkleri savaşla tehdit etmiştir (Osmanlı Belgelerinde Millî Mücadele ve Mustafa Kemal Atatürk, 2007, s.109; İnönü, II, s.37-38). Burada İngiltere'nin tarihi süreçte kurnazca ürettikleri politikaları ve öne sürdüğü blöfleri unutmamak gerekir. İngiltere görüşmeler sırasında da bu kurnaz siyasetinden bir sonuç alacağını ümit etmiş ve üstü kapalı olarak İsmet Paşa'yı savaşla tehdit etmiştir. Bu durumu bir blöf olarak değerlendirmek mümkündür. Çünkü İngiltere gerek askeri gerekse de ekonomik olarak TBMM'den güçlü olmasına rağmen, Büyük Taarruz'dan sonra müttefiklerinden Yunanlılara asker takviyesi istemiş ve olumlu bir sonuç alamamıştır. Bunun yanında İngiltere halkı da topraklarında devam etmeyen bir savaş için İngiltere ekonomisinin gereksiz yere harcanmaması gerektiğini istiyorlardı. Ayrıca kamuoyu, basın ve diğer İtilaf Devletleri de İngiltere aleyhine bir tutum geliştirmişlerdir. Mustafa Kemal Paşa ve İsmet Paşa İngiltere'nin bu davranışının blöf olduğunu ve onların tekrar bir savaşı göze alamayacağını bilmekteydiler. Bu nedenle İsmet Paşa, Konferans boyunca dik durmuş ve İngiltere'nin bu tehditlerine boyun eğmemiştir.

5 Ekim'de kesintiye uğrayan görüşmeler 7 Ekim'de tekrar başlamıştır. İtilaf Devletleri Türklerin, Yunan askeri kuvvetlerinin Meriç nehrinin sol tarafına çekilmesi isteğini makul görmüşler ve bunu kabul ettiklerinin belirtmişlerdir (Sürmeli, 2007, s.58-60). Bundan sonra devam eden görüşmeler, iki gün daha çetin bir biçimde sürdürülmüştür. Hem İsmet Paşa'nın hem de İtilaf Devletleri temsilcilerinin ortaya koyduğu şartlar artık ya 
savaşı devam ettirecek ya da bitirecekti. Bu durum her iki tarafında canını sıkmaktaydı. Bu nedenle konağın deniz tarafında bulunan balkonunda İngiliz iki deniz subayı ellerinde işaret bayraklarıyla beklemişlerdir. Eğer antlaşma olumlu geçerse bu işaret bayrakları ile verilen emirleri biraz ileride bekleyen İngiliz gemisine ileteceklerdi (Karacan, 1971, s.40-45).

General Harington, 10 Ekim 1922'de Salı günü saat 17.00'de Mudanya'ya gelmiş ve diğer müttefikleri olan general Charpy ve general Mombelli ile gemide bir görüşme yapmıştır. Saat 18.00'de tekrar konağa gelerek konferansı başlatmışlardır. Görüşmeler iki saat kadar sürmüş ve 21.00 'de sona ermiştir. İtilaf Devletleri temsilcileri tekrar gemilerine dönmüşlerdir. Artık iş sadece antlaşmanın imzalanmasına kalmıştır. Temsilciler, gece saat 03.00 'de tekrar konağa gelmişler ve üzerinde çalıştıkları protokol müsveddelerini okuyup tartışmışlardır. Türklerinde üzerinde mutabık olduğu bu metin temize çekilmiş ve sabaha doğru 05.15'de dinlenmek üzere görüşmelere ara verilmiştir. Bu sırada Mudanya'da yaşayan halk bütün gece uyumamış ve binanın etrafında görüşmenin sonucunu beklemişlerdir. Her ne kadar gerginlikler yaşandıysa da hem Türklerin hem de İtilaf Devletlerinin kabul ettiği antlaşma maddeleri 11 Ekim'de sabah 06.43'te Yunanistan temsilcisi dışında herkes tarafından bütün sayfalarını tek tek imzalamıştır (Yalman, 1996, s.199).

Yunanistan, Doğu Trakya'dan geri çekileme konusunda adım atmamaya çalışmış ve burada sınırın Meriç nehrinin solu değil de 1915 yılında Meriç’in doğusunda olan bölge olmasını istemiştir. Yunanlıları Meriç'in doğusunda kalmaları için diğer ülke temsilcileri ve özellikle İngiliz temsilci Harrington ikna etmeye çalışmışlardır. Bu antlaşmayı Yunan temsilcisi ilk başta imzalamamış Yunanlıların Meriç'in doğusunda kalması için diretmeyi sürdürmüştür. Fakat Harrington'un Mudanya Ateşkes Antlaşmasının herkes tarafından uygulanacağı ve bu yönde kararlı olduklarını açıklamasından üç gün sonra Yunanlılarda imzalamak zorunda kalmıştır. Çünkü en büyük destekçileri İngiltere'ydi, onların istemediği bir şeyi Yunanlıların devam ettirmesi mümkün değildi. Yunanlıların da imzalaması sonucunda, Mudanya Ateşkes Antlaşması 15 Ekim 1922 tarihinde yürürlüğe girmiştir (Hâkimiyet-i Milliye, 12-15 Ekim 1922; TBMM Zabıt Ceridesi, Dönem I, Cilt 23, 1960, s. 349,350; Osmanlı Belgelerinde Millî Mücadele ve Mustafa Kemal Atatürk, s.108; Yeşilbursa, 2019, s.1025).

İsmet Paşa, Ankara'ya çekmiş olduğu telgrafta antlaşmanın 11 Ekim 1922'de saat 06.00'da imzalandığını bildirmiştir. Bu haber TBMM'de adeta bir sevinç havası oluşturmuş ve meclis koridorunda milletvekilleri birbirleri ile kucaklaşarak bu zaferi kutlamışlardır. Konferansın son oturumunda önce general Harrington, sırasıyla TBMM Hükümetine, sonra Başkumandan Mustafa Kemal Paşa'ya akabinde ise İsmet Paşa'ya teşekkür etmiştir. Ayrıca Genelkurmay mensuplarına, Türk halkı ve temsilcilerine ve Mudanya kasabasında yaşayan halka da ayrı teşekkür etmiştir: "Tanışmayarak geldik, dost olarak gidiyoruz ve bu hissi daima muhafaza edeceğiz" demiştir (Yalman, 1996, s.199). General Harrington'dan sonra diğer generaller de ev sahibi sıfatıyla kendilerine iyi nezaket gösterdiği için İsmet Paşa'ya teşekkür etmişlerdir. İsmet Paşa'da nezaketli davrandıkları için onlara teşekkür etmiş ve onları konak önünde bulunan bir askeri bando eşliğinde, asker selamı vererek rıhtımda bulunan gemilerine uğurlamıştır. Mustafa Kemal Paşa, Büyük Taarruz'dan sonra 9 Eylül'de İzmir'e girdiği vakit, artık Milli Mücadele'nin askeri safhasının bittiğini ve ikinci safhayı açmalarının gerektiğini söylemiştir (Aydemir, III, 2016, s.38,39). Bundan sonra Türk milletinin önünde açllan ve hiç kapanmayacak olan askeri zaferleri ilim ve kültürle taçlandırma devresi başlayacaktır.

\section{Mudanya Ateşkes Antlaşması'nın Önemi ve Sonuç}

Mudanya Ateşkes Antlaşması 14 madde olarak imzalanmıştır. Bu antlaşma ile İtilaf devletleri TBMM'yi resmen tanımışlardır. Bu antlaşma, Türklerle Yunanlılar arasında üç yıldan fazla süre devam eden çatışmayı durdurmuş ve Yunanlılar'ın Batı Anadolu'dan çıkartılmasına zemin hazırlamıştır. Antlaşma ile artık Türk topraklarında hiçbir yabancı asker kalmamış ve Türkler için savaşın askeri safhası sona ermiştir. Bundan sonra sıcak çatışmalar olmayacak ve bir karar masa başında verilecektir. Antlaşmanın en önemli taraflarından birisi 
de Doğu Trakya üzerinde olmuştur. Doğu Trakya savaş yapılmadan Yunanlılardan alınmıştır. Türk ve Yunan sınırı Meriç nehri olarak kabul edilmiştir. Bu sınır halen günümüzde de geçerliliğini korumaktadır (Hâkimiyeti Milliye, 15 Ekim 1922; TBMM Zabıt Ceridesi, Dönem I, Cilt 23, 1960, s.350; Soysal, I, 1983, s.60-70; Türkgeldi, 1948, s.185-188).

Antlaşmanın imzalanmasından sonra Doğu Trakya'da bulunan Türkler çok rahatlamıştır. Çünkü Yunan işgali altında bölgede tarihte görülmemiş yıkım ve sayısız ölüm görmüşlerdir. Bölgenin asayişi alt üst olmuştu. Yunanistan Türkleri yer altı çeteleriyle ve kanun dışı yollarla kontrol altında tutmak istemiştir. Bölgenin Türklere verildiğini duyan Rum göçmenler bir an önce Yunanistan’a taşınmak istemişlerdir. Tekirdağ-Selanik arasında hem trenlerle hem de hem de çeşitli vasıtalarla göç etmeye başlamışlardır. Tanin gazetesinin belirttiğine göre bir ay içinde neredeyse 650.000 bin Rum nüfus Yunanistan'a göç etmiştir. Bu nüfusun büyük bir kısmını ise Doğu Trakya'dan göçen Rumlar oluşturmuştur (Tanin, 20-25 Ekim 1922; Tanin, 4-5 Aralık 1922).

Türkler her ne kadar masa başında isteklerini kabul ettirmeye çalıştılarsa da bunda büyük oranda başarılı oldukları görülmektedir. Fakat bu antlaşmanın Türklerin aleyhine olan maddeleri de olduğu anlaşılmaktadır. Türklerin iç güvenliklerini sayısı 8000 bini aşmayacak bir Jandarma kuvveti ile korumaları bir nevi Türklerin iç işlerine müdahaledir. Bunun yanında Türk kuvvetlerinin Çanakkale Boğazı ve İzmit’te belirlenen çizgiyi geçemeyecekleri maddesi ile Türkler kendi sınırları içerisinde bulunan boğazlar üzerinde tam bir kontrol sağlanması durumunu elde edememişlerdir. Boğazlar üzerinde tam bir hakimiyet sağlanmaması durumu Lozan Barış Antlaşması'nda da kabul edilmiştir. Türkler Boğazlar üzerinde tam bir hakimiyet elde etme durumunu ancak 1936 yılında imzalanan Montrö Boğazlar Antlaşması ile elde edebilmişlerdir. Antlaşmada yer alan, bir barış antlaşması yapılana kadar Türklerin Doğu Trakya'da ne bir asker bulunduracak ne de bir ordu toplamayacağı şartı ileride yapılacak olan Lozan Barış Antlaşması sırasında pazarlık etme gücünü sinırlandırmıştır.

Yunan askeri kuvvetlerinin işgal ettiği yerlerden çekilmesi ve İtilaf Devletleri kontrolünde bulunan yerlerin Türk kuvvetlerine devri otuz gün içinde tamamlanmıştır. Kasım ayının sonuna kadar bütün Doğu Trakya anavatana katılmış ve artık Anadolu'nun hiçbir yerinde Yunan askeri kalmamıştır. Antlaşmanın en önemli bir tarafı da Türkiye Büyük Millet Meclisi hükümetinin İtilaf Devletleri tarafından resmen tanınmış olduğudur. Artık İtilaf Devletleri Türklerin temsilcisi olarak Osmanlı Devleti’ni değil TBMM’yi muhatap almıştır. Askeri güç ile kazanılan savaş, masa başında İsmet Paşanın yoğun gayretleriyle mühim bir antlaşmaya dönüşmüştür (Eraslan, 2005, s.358). Bütün bu başarılar bir yıl sonra imzalanacak olan Lozan Barış Antlaşmasında TBMM’nin elini daha da güçlendirmiştir.

Son söz olarak bu çalışmada Mudanya Ateşkes Antlaşmasına gidilen süreçte ve anlaşmanın imzalanma sürecinde yaşanan gelişmeler, bilgiler ışığında ele alınarak incelemiş ve değerlendirilmiştir. Özellikle bu konu ile ilgili yapılan çalışmalarda detaylı anlatılmayan Mudanya Ateşkes Antlaşmasına imzalanma sürecinde yaşanan gelişmeler, biraz genişletilerek detaylandırılmış ve ne kadar önemli olduğuna dair vurgu yapılmaya çalışılmıştır.

\section{Kaynakça}

Akın, V. (2002). Mudanya mütarekesi ve Trakya'nın kurtuluşu. Hasan Celal Güzel, Kemal Koçak, Salim Koca (Ed.), Türkler: Cilt 16. (s.219-229) içinde. Ankara:Yeni Türkiye Yayınları. Erişim adresi: https://www.academia.edu/28649882/T\%C3\%BCrkler_Cilt_16_pdf

Akyüz, Y. (1988). Türk kurtuluşsavaşı ve fransız kamuoyu. Ankara: Türk Tarih Kurumu Yayınları. 
Alper, S. (2013). Mudanya ateşkes antlaşması Atatürk’ün diploması zaferi. Hukuk Gündemi (Atatürk Özel Sayısl), 30-34. Erişim adresi: http://www.ankarabarosu.org.tr/Siteler/19442010/Dergiler/HukukGundemiDergisi/2013-1.pdf

Altuncuoğlu, N. \& Erdoğan, A. (2019). Arşiv belgeleri ışığında Mustafa Kemal Paşa’nın askerlikten istifa süreci. Journal of Universal Studies, 2(1), 62-71. https://doi.org/10.38000/juhis.508754

Aralov, S. İ. (1985). Bir sovyet diplomatının Türkiye anıları. Ankara: Birey ve Toplum Yayınları.

Arı, K. (2008). Osmanlıdan işgal yıllarına mütarekeden cumhuriyet günlerine mudanya. Dörtok Abacı (Haz.) kitabının içinde, Mudanya bırakışması'na uzanan süreçte girişimler ve doğu trakya sorunu (s.98-107), Bursa: Gaye Yayınevi.

Atatürk ile ilgili arşiv belgeleri, 1911-1921 tarihleri arasına ait 106 belge. (1982). Ankara: Başbakanlık Osmanlı Arşivi Daire Başkanlığı Yayınları. Atatürk'ün Samsuna çıkışı ve kurtuluş savaşı'nın başlatılmasına dair belgeler. (1999).

Cemalettin Taşkıran ve diğerleri (Haz.). Ankara: Genelkurmay Başkanlığı ATESE Yayınları. Aydemir, Ş. S. (2016). Tek adam (Cilt III). İstanbul: Remzi Kitapevi.

Başyiğit, T. (2007). Anılarda mudanya ateşkes antlaşması. ÇTTAD, 6(14), 177-184. Erişim adresi: https://dergipark.org.tr/tr/download/article-file/233309

Biyıklığlu, T. \& Ercan. T. (1962). Türk istiklal harbi mondros mütarekesi ve tatbikatı (Cilt I). Ankara: Genelkurmay ATASE Yayınları.

Budak, M. (1995). Mütareke döneminde itilaf devletlerinin müdahaleleri (30 Ekim 1918- 15 Mayıs 1919). İlmi Araştırmalar, 5, 81-105. Erişim adresi: https://dergipark.org.tr/tr/download/article-file/73210

Çankaya, N. (1995). Atatürk'ün hayatı, konuşmaları ve yurt gezileri, Ankara: Tifduruk Yayınları.

Çevik, Z. (2016). Milli mücadele'de kocaeli grubu ve son kurşun, 3-5 Nisan 2015 Uluslar arası Karamürsel Alp ve Kocaeli Tarihi Sempozyumu-II (s. 1551-1589) içinde. Kocaeli: Kocaeli Büyükşehir Belediyesi Yayınları. Erişim adresi: http://www.kocaelitarihisempozyumu.com/bildiriler2/106.pdf

Çınar, B. \& Yalçınkaya. H. (2009). Blitzkrieg'in II. dünya savaşı öncesi uygulaması: büyük taarruz, CTAD, 5(9). 77-96. Erişim adresi: https://www.academia.edu/38351345/Blitzkrieg_in_II_D\%C3\%BCnya_Sava\%C5\%9F\%C4\%B1_\%C3 \%96ncesi_Uygulamas\%C4\%B1_B\%C3\%BCy\%C3\%BCk_Taarruz

Eraslan, C. (2005). Mudanya mütarekesi. Diyanet Vakfi İslam Ansiklopedisi: Cilt 30 (s. 356-359) içinde. (Cilt 30, 356-359 ss.). İstanbul: Diyanet Vakfi Yayınları. Erişim adresi: https://cdn2.islamansiklopedisi.org.tr/dosya/30/C30009858.pdf

Gazi Mustafa Kemal. (2015). Nutuk, N. Bayramoğlu \& K. Güran (Ed.). Ankara: Kaynak Yayınları.

Goloğlu, M. (2010). Cumhuriyet’e doğru, İstanbul: Türkiye İş Bankası Kültür Yayınları.

Hâkimiyet-i Milliye Gazetesi. 20 Ağustos 1922.

Hâkimiyet-i Milliye Gazetesi.20-26 Ağustos 1922.

Hâkimiyet-i Milliye Gazetesi. 27 Ağustos 1922.

Hâkimiyet-i Milliye Gazetesi. 27 Ağustos 1922.

Hâkimiyet-i Milliye Gazetesi. 2 Eylül 1922.

Hâkimiyet-i Milliye Gazetesi. 4 Eylül 1922.

Hâkimiyet-i Milliye Gazetesi. 9 Eylül 1922.

Hâkimiyet-i Milliye Gazetesi. 18 Eylül 1922.

Hâkimiyet-i Milliye Gazetesi. 20 Ağustos 1922- 1 Eylül 1922.

Hâkimiyet-i Milliye Gazetesi. 12 Ekim 1922. 
Hâkimiyet-i Milliye Gazetesi. 12-15 Ekim 1922.

Hâkimiyet-i Milliye Gazetesi. 15 Ekim 1922.

İnönü, İ. (1987). Hatıralar (Cilt II). Ankara: Bilgi Yayınevi.

Jaeschke. G. (1970). Türk kurtuluşsavaşı kronolojisi (Mondros'tan mudanya'ya kadar), Ankara:Türk Tarih Kurumu Yayınları.

Karacan, A. N. (1971). Lozan. (2. Baskı). İstanbul: Milliyet Yayınevi.

Kılıç, S. (2016). İstiklal harbi’nde sovyetler birliği'nden gelen yardımlar. DTCF Dergisi, 56(1), 124-143. doi: 10.1501/Dtcfder_0000001467

Kurtcephe, İ. ve Beden, A. (1999). Türkiye Cumhuriyeti tarihi. Ankara: Alp Yayınevi.

Müderrisoğlu, A. (1990). Kurtuluş savaşı’nın mali kaynakları. Ankara: Atatürk Araştırma Merkezi Yayınları.

Onar, M. (1991). Atatürk'ün kurtuluşsavaşı yazışmaları I. Ankara: Kültür Bakanlığı Yayınları.

Orbay, R. (1993). Cehennem değirmeni, siyasî hatıralarım (Cilt I). İstanbul: Emre Yayınları.

Osmanlı belgelerinde millî mücadele ve Mustafa Kemal Atatürk. (2007). Ankara: T.C. Başbakanlık Devlet Arşivleri Genel Müdürlüğü Osmanlı Arşivi Daire Başkanlığı Yayınları.

Önder, M. (1972). Akşehir'de garp cephesi karargahı ve büyük taarruz kararı, Büyük Zaferin 50. Yıldönümüne Armağan. İstanbul: Başbakanlık Kültür Müsteşarlığı Kültür Yayınevi.

Semiz, Y. ve Toplu, G. (2017). Milli mücadele döneminde Konya ve Atatürk. OPUS - Uluslararası Toplum Araştırmaları Dergisi, 7(12), 254- 283. Erişim adresi: https://dergipark.org.tr/tr/download/articlefile/317505

Sofuoğlu, A. (2002). Mondros mütarekesi sonrası Türkiye'nin işgaline karşı milli direniş: Kuvay-i milliye (1918-1921). Hasan Celal Güzel, Kemal Koçak, Salim Koca (Ed.), Türkler: Cilt 15. (s. 618-629) içinde. Ankara: Yeni Türkiye Yayınları. Erişim adresi: https://www.academia.edu/28649881/T\%C3\%BCrkler_Cilt_15_pdf

Soysal, İ. (1983). Tarihçeleri ve açıklamaları ile birlikte Türkiye'nin siyasal antlaşmaları (1920-1945) I. Ankara: Türk Tarih Kurumu Yayınları.

Sürmeli, S. (2007). General charles harington'un 1920-1923 dönemi Türkiye raporu ve döneme dair raporla ilgili değerlendirmeler. Atatürk Dergisi, 5(4), 25-86. Erişim adresi: https://dergipark.org.tr/tr/download/article-file/26224

Şahin, H. H. (2019). Osmanlı devleti ile Hindistan müslümanlarının tarihî bağı ve hindistan hilafet hareketi. Kafkas Üniversitesi Sosyal Bilimler Enstitüü̈ Dergisi, 24, 731-754. doi: 10.9775/kausbed.2019.063

Şimşir, B. (1984). İngiliz belgelerinde Atatürk (Cilt 4). Ankara: Türk Tarih Kurumu Yayınları.

Tanin Gazetesi. 20-25 Ekim 1922.

Tanin Gazetesi. 4-5 Aralık 1922.

Tarih IV, Türkiye cumhuriyeti. (1931). Türk Tarihi Tetkik Cemiyeti (Haz.). İstanbul: Devlet Yayınevi.

Turan, Ş. (2003). İsmet inönü yaşamı, dönemi ve kişiliği, (2. Baskı). Ankara: Bilgi Yayınevi.

Türk istiklâl harbi, mondros mütarekesi ve tatbikatı (Cilt I). (1962) Ankara: Genelkurmay Başkanlığı Harp Tarihi Dairesi Yayınları.

TBMM zabıt ceridesi. (1960). Dönem I. Cilt 23. Ankara: TBMM Yayınları.

Türk istiklal harbi, güney cephesi (Cilt IV). (2009). (Genel Kurmay Askeri Tarih ve Stratejik Etüt Başkanlığı, Haz.). Ankara: Genel Kurmay Başkanlığı Yayınları.

Türk silahlı kuvvetleri tarihi, TBMM hükümeti dönemi (Cilt IV), (1984), Ankara: Genelkurmay ATASE Yayınları. 
Türkgeldi, A. (1948). Mondros ve mudanya mütarekelerinin tarihi. Ankara: Türk Devrim Tarihi Enstitüsü Yayınları.

Türkmen, Z. (2010). Büyük taarruz harekatı. Atatürk ve büyük taarruz kahramanlarına armağan. G. Şahin (Ed.). Afyonkarahisar: Afyon Kocatepe Üniversitesi Yayınları.

Üçüncü, U. (2012). Türk kamuoyunda büyük taarruz. Ankara: Altınpost Yayınevi.

Vakit Gazetesi. 18 Kasım 1918.

Yalman, A. E. (1996). Mudanya bırakışması ve yankıları. Atatürk Yolu Dergisi, 5(18). 189-203. Erişim adresi: https://dergipark.org.tr/tr/download/article-file/20702

Yeşilbursa, B. K. (2019). İngiliz yıllık raporlarına göre mudanya mütarekesi (3-11 Ekim 1922). Mondros mütârekesi'nin 100. yılı: I. dünya savaşı'nın sonu mütârekeler ve barış antlaşmaları uluslararası sempozyumu bildiriler kitabı II (s. 1009-1033) içinde. Ankara: Atatürk Araştırma Merkezi Yayınları.

Yüceer, S. (2017). Bir ütopyanın gerçekleşmesi: Tam bağımsız Türkiye ve misak-ı milli, Yeni Türkiye: Misak-ı Milli Özel Sayısl, 23(93). 141-148. Erişim adresi: https://kutuphane.ttk.gov.tr/details?id=586152\&materialType=KT\&query=Yavuz\%2C+Mustafa.

\section{Extended Abstract}

\section{Purpose}

When we examined the articles written about the Mudanya Treaty so far, we saw that all the developments in the process of signing the Mudanya Treaty were not explained and explained incompletely. What makes this article different from other articles is that this missing part of the Mudanya Agreement is explained. Because the treaty has led the Ankara Government of the Republic of Turkey signed the deed of the Lausanne Treaty process. It is İsmet (İnönü) Pasha who signed both the Mudanya Treaty and the Lausanne Treaty on behalf of the Ankara Government. Therefore, this article is necessary in terms of explaining the relations between the Ankara Government and the representatives of the Entente States before the signing of the Mudanya Armistice.

\section{Design and Methodology}

Mudanya Armistice constituted a very important building block in the process leading to Lausanne in the first quarter of the 20th century. Despite many studies have been carried out on Mudanya Armistice before, this study aims to discuss the agreement in all aspects. Therefore, in this article, we evaluated the developments that took place in that period with the Great Offensive, which enabled the signing of the Mudanya Armistice, and interpreted the events from a different perspective.

The paper is a review study. Although it is a review paper, it is an original article in terms of the content of the subject. In order to add originality to this study, archival documents were reviewed. The issues of Hâkimiyet-i Milliye Newspaper, the official media organ of the Ankara Government in those years, which were published between 20 August and 15 October 1922 were included in the study. Besides, the study also benefited from the Republican History Archive and also the 'ATASE' Published Archival Documents. At last, the books published by the newspaper, 'TBMM Zabit Cerideleri' and 'ATASE' were also reviewed. 


\section{Findings}

With this treaty, the Entente states officially recognized the Turkish Grand National Assembly. This treaty is one of the most profitable treaties the Turks signed during the War of Independence. The treaty stopped the conflict between Turks and Greeks for three years and the Greeks were expelled from Western Anatolia. With the treaty, there were no foreign soldiers left in the Turkish lands and the military phase of the war ended for the Turks. After that, there will be no hot conflicts and the final decision will be made at the table. One of the most important parties of the treaty was on Eastern Thrace. Eastern Thrace was taken from the Greeks without war. The Turkish and Greek border has been accepted as the Meriç river. This limit is still valid even today.

After the signing of the treaty, the Turks in Eastern Thrace were very relieved. Because, under the Greek occupation, they have seen fires, destruction and countless deaths in the region that have not been seen in the history. The order of the region was turned upside down. Greece wanted to keep the Turks under control through underground gangs and illegal means. Having heard that the region was given to Turks, Greek immigrants wanted to move to Greece as soon as possible. They started to migrate between Tekirdağ and Thessaloniki both by trains and by various means. According to Tanin newspaper, almost 650,000 Greek population immigrated to Greece in a month. A large part of this population was composed of Greeks immigrating from Eastern Thrace.

Although the Turks tried to get their requests accepted at the desk, it is seen that they were successful in this to a large extent. However, it is seen that this treaty also has articles against the Turks. The fact that the Turks protect their internal security with a Gendarmerie, whose number will not exceed 8000 thousand, is a kind of intervention in the internal affairs of the Turks. In addition, with the provision that Turkish forces cannot cross the line determined in the Dardanelles and Izmit, the Turks could not achieve full control over the straits within their borders. The lack of full control over the Straits was also accepted in the Lausanne Peace Treaty.

\section{Research Limitations}

This article named "Armistice Of Mudanya In The Process Through Lausanne Agreement Mudanya Treaty in the Process Leading to Lozan" covers the events of 1922 in general and the events occurred between July to September in 1922 in terms of boundaries and scope.

\section{Originality}

This study is an original article in terms of narrating, expressing and evaluating events. With the addition of archival documents of the period this study presents an alternative approach to the role of the Armistice Of Mudanya .

Araştırmacı Katkısı: Ömer Faruk Kırmıt (\%100). 